1 Fraser J, Henrichsen T, Mok Q, Tasker R. Prolonged mechanical ventilation as a consequence of acute illness. Arch Dis Child 1998;78:253-6.

2 Simonds AK. From intensive care unit to home discharge in the 24 hour ventilator-dependent patient. Eur Respir Mon 1998;8:364-79.

3 Fraser J, Mok Q, Tasker R. Survey of occupancy of paediatric intensive care units by children who are dependent on ventilators. BMJ 1997:315:347-8.

4 Davies RH, Harvey I, Newton-John H, Ward TA. Home ventilation of a child with motor and sensory neuropathy. BMJ 1996;313:153-5.

5 Frates RC, Splaingard ML, Smith EO, Harrison GM. Outcome of home mechanical ventilation. J Pediatr 1985;106:850-6.

6 Eigen $\mathrm{H}$, Zander J. Home mechanical ventilation of pediatric patients. Am Rev Respir Dis 1990;141:258-9.

7 Fields AI, Rosenblatt A, Pollack MM, Kaufman J. Home care cost-effectiveness for respiratory technology-dependent children. $\mathrm{Am} \mathrm{J}$ Dis Child 1991;145:729-33.

8 Robinson RO. Ventilator dependency in the United Kingdom. Arch Dis Child 1990;65:1235-6.
9 Barker I. Central funding and a central resource providing information are needed. BMJ 1996;313:940.

10 Newton-John HF. Long-term mechanical ventilation of patients in Australia. Med J Aust 1989;150:3-6.

11 Dhillon JS, Frewen TC, Singh NC, Speechley KN. Chronic mechanical ventilation-dependent children in Canada. Paediatr Child Health 1996;1:111-6.

12 Fauroux B, Howard P, Muir JF. Home treatment for chronic respiratory insufficiency: the situation in Europe in 1992. The European working group on home treatment for chronic respiratory insufficiency. Eur Respir J1994;7:1721-6

13 Goldberg AI, Faure AM, Vaughan CJ, Snarski R, Seleny FL. Home care for life-supported persons: an approach to program development. J Pediatr 1984;104:785-95.

14 Jardine E, Wallis C. Core guidelines for the discharge home of the child on long-term assisted ventilation in the United Kingdom. Thorax 1998;53:762-7.

(Accepted 9 November 1998)

\title{
Dilemmas in treating early prostate cancer: the evidence and a questionnaire survey of consultant urologists in the United Kingdom
}

\author{
Jenny L Donovan, Stephen J Frankel, Alex Faulkner, Sara Selley, David Gillatt, Freddie C Hamdy
}

Evidence based medicine suggests that evidence of effectiveness should accumulate, preferably from randomised controlled trials, before treatments for any condition become widely used. The case of localised prostate cancer shows how difficult this can be in practice. The suitability of population screening for localised prostate cancer has been debated, ${ }^{12}$ with particular concerns about the comparative effectiveness of the main treatments for the disease: radical prostatectomy, radical radiotherapy, and conservative management (also known as watchful waiting or surveillance). ${ }^{34}$ Systematic reviews show that published evidence is limited to two seriously flawed randomised controlled trials and a range of observational studies with biases relating to patient selection, variable treatment techniques, outcome assessments, and methods of data analysis. ${ }^{3}$ These studies show that 10 year survival is good and overlaps for the three treatments, being $85-90 \%$ for radical prostatectomy, $65-90 \%$ for radical radiotherapy, and $70-90 \%$ for conservative management. ${ }^{3}$ Although some studies indicate a survival advantage of radical treatments in some patients, this advantage is small and uncertain given the particular study designs. Furthermore, quality of life may be worse among those receiving radical treatments because of resulting complications. ${ }^{5}$ For example, after radical prostatectomy up to $3 \%$ of patients may be totally incontinent, with up to $60 \%$ "dribbling" urine, and 20-80\% impotent, while after radical radiotherapy up to $36 \%$ may have damage to adjacent organs, $10 \%$ incontinence, and 40\% impotence. ${ }^{3}$ Morbidity from conservative management relates to symptoms (and hormonal treatment if required) if the disease progresses.

\section{Subjects, methods, and results}

A postal questionnaire survey of practising consultant urologists registered with the British Association of Urological Surgeons was conducted exploring their treatment preferences for various clinical case vignettes. General surgeons, trainees, and those with paediatric caseloads were excluded. A total of 244 consultant urologists replied (response rate 60\%). Urologists had a mean of 14.1 years' experience (range 2-30 years), and 130 of them managed 100 patients or more with prostate cancer. Expertise in performing radical prostatectomy was restricted to comparatively few urologists-98 reported having ever performed the procedure and only $12(14 \%)$ that they performed 20 or more operations per year. The table shows that radical treatments were the first choice treatment for all hypothetical patients with apparently localised disease under the age of 70 years (cases 1, 2, 3, and 5 in table), irrespective of mode of presentation, prostate specific antigen concentration, and grade of tumour. Radical prostatectomy was preferred for the man of 55 (case 1), radical radiotherapy for the man of 69 (case 3). Conservative management was first choice for the majority of urologists for the man of 75 (case 4). For the youngest men (cases 1 and 5) only a few urologists selected conservative management, rising to $27 \%$ for the man aged 69.

\section{Comment}

Although reliable evidence supporting radical treatments is scarce, British urologists seem to favour them for all patients under 70 . These findings may be open to misinterpretation, representing what urologists say they do rather than what they do, although hospital episode statistics confirm that numbers of radical prostatectomies have doubled nearly every year between 1990-1 and 1994-5 in the United Kingdom (hospital episode statistics, 1989-90 to 1994-5).

Clearly, evidence is needed from randomised controlled trials, but such studies have proved difficult because of perceptions that patients are reluctant to accept conservative management. New methodological approaches are required urgently to investigate this
Editorial

by Emberton

Department of Social Medicine, University of Bristol, Canynge Hall, Bristol BS8 2PR

Jenny L Donovan, senior lecturer Stephen J Frankel, professor

Alex Faulkner, research associate

Sara Selley, research associate

Bristol Urological Institute,

Southmead

Hospital, Bristol

BS10 5NB

David Gillatt,

consultant urologist

University Urology

Unit, Freeman

Hospital, Newcastle

upon Tyne,

NE7 7DN

Freddie C Hamdy, consultant senior

lecturer

Correspondence to: Mr Hamdy

F.C.Hamdy@ncl.ac.uk

BMJ 1999;318:299-300 
First choice of treatment of consultant urologists for clinical vignettes. Values are numbers (percentages) of consultants

\begin{tabular}{|c|c|c|c|c|c|c|c|c|c|}
\hline $\begin{array}{l}\text { Case } \\
\text { No }\end{array}$ & Presenting characteristics* & $\begin{array}{l}\text { No of } \\
\text { consultants } \\
\text { responding }\end{array}$ & $\begin{array}{c}\text { Radical } \\
\text { prostatectomy }\end{array}$ & $\begin{array}{l}\text { Radical } \\
\text { radiotherapy }\end{array}$ & Brachytherapy & $\begin{array}{l}\text { Hormone } \\
\text { (medical) }\end{array}$ & $\begin{array}{l}\text { Hormone } \\
\text { (surgical) }\end{array}$ & $\begin{array}{l}\text { Surveillance } \\
\text { only }\end{array}$ & $\begin{array}{l}\text { Surveillance } \\
\text { and hormone }\end{array}$ \\
\hline 1 & $\begin{array}{l}\text { Age } 55 \text {, incidental, prostate specific antigen } 7 \mathrm{ng} / \mathrm{ml} \text {, } \\
\text { transrectal ultrasound and magnetic resonance } \\
\text { imaging results suggest localised tumour, Gleason } \\
\text { score } 3\end{array}$ & 211 & $136(64)$ & $49(23)$ & $1(0.5)$ & $3(1)$ & 0 & $16(8)$ & $6(3)$ \\
\hline 2 & $\begin{array}{l}\text { Age 62, bladder outlet obstruction, prostate specific } \\
\text { antigen } 15 \mathrm{ng} / \mathrm{ml} \text {, Gleason score } 5 \text { from chippings }\end{array}$ & 202 & $80(40)$ & $82(41)$ & 0 & $7(3)$ & $3(1)$ & $10(5)$ & $20(10)$ \\
\hline 3 & $\begin{array}{l}\text { Age } 69 \text {, incidental, prostate specific antigen } \\
16 \mathrm{ng} / \mathrm{ml} \text {, transrectal ultrasound and magnetic } \\
\text { resonance imaging results suggest localised } \\
\text { tumour, Gleason score } 3\end{array}$ & 206 & $50(24)$ & $85(41)$ & $2(1)$ & $13(6)$ & 0 & $27(13)$ & $29(14)$ \\
\hline 4 & $\begin{array}{l}\text { Age } 75 \text {, incidental, prostate specific antigen } \\
20 \mathrm{ng} / \mathrm{ml} \text {, transrectal ultrasound and magnetic } \\
\text { resonance imaging results suggest localised } \\
\text { tumour, Gleason score } 3\end{array}$ & 218 & 0 & $51(23)$ & 0 & $22(10)$ & $1(0.5)$ & $52(24)$ & $92(42)$ \\
\hline 5 & $\begin{array}{l}\text { Age } 58 \text {, poorly differentiated localised tumour, } \\
\text { prostate specific antigen } 17 \mathrm{ng} / \mathrm{ml} \text {, Gleason score } 8\end{array}$ & 202 & $67(33)$ & $102(50)$ & $2(1)$ & $23(11)$ & $1(0.5)$ & $1(0.5)$ & $6(3)$ \\
\hline
\end{tabular}

*Normal values of prostate specific antigen are around $4 \mathrm{ng} / \mathrm{ml}$. In Gleason grading system sections of tumour are graded from 1 (least aggressive) to 5 (most aggressive). The two highest grades from each tumour are added to give a score ranging from 2-10. Scores of 7 and above indicate worse prognosis than lower scores.

issue and to bridge the gap between clinical practice and the need to acquire evidence. Such approaches need to retain the essential principle of randomisation while incorporating more fully patients' perspectives and preferences. Without this, the increasing availability of radical treatments, rising rate of detection of localised prostate cancer in younger men, the concerns of men about harbouring an untreated malignancy, and the desire of clinicians to cure patients if at all possible will combine to ensure that the situation cannot resolve spontaneously. Trials undoubtedly need to be mounted, and until more evidence accumulates, patients and urologists should use the information available from recent systematic reviews ${ }^{34}$ to reach shared decisions about treating localised prostate cancer-information that highlights uncertainties about the potential effects of such treatments on survival and quality of life.

The list of urological surgeons was kindly provided by the British Association of Urological Surgeons. The views expressed in this paper are those of the authors and not necessarily those of the Standing Group on Health Technology, the HTA Commissioning Board, the HTA Panel members, or the Department of Health.
Contributors: JLD led and coordinated the study, cowrote the systematic review, helped to design the questionnaire, and analysed the questionnaire data. SJF initiated the study. AF supervised the collection and appraisal of the literature, cowrote the systematic review, and helped to design the questionnaire and analyse the data. SS collected and appraised the literature and helped to design the questionnaire. DG provided clinical expertise during the appraisal of the literature and completion of the review. FCH provided essential urological input to the manuscript. The manuscript was written jointly by JLD, FCH, SJF, AF, and DG. JLD, FCH, SJF, and AF are guarantors of the paper.

Funding: The systematic review and questionnaire survey were supported by a grant from the NHS health technology assessment programme.

Conflict of interest: None.

1 Stewart-Brown S, Farmer A. Screening could seriously damage your health. BMJ 1997;314:533.

2 Woolf SH. Should we screen for prostate cancer? BMJ 1997;314:989-90.

3 Selley S, Donovan JL, Faulkner A, Coast J, Gillatt D. Diagnosis, management and screening of early localised prostate cancer. Health Technol Assess 1997;1(2)

4 Chamberlain J, Melia J, Moss S, Brown J. The diagnosis, management, treatment and costs of prostate cancer in England and Wales. Health Technol Assess 1997;1(3).

5 Litwin MS, Hays RD, Fink A, Ganz PA. Quality of Life outcomes in men treated for localized prostate cancer. JAMA 1995;273:129-35.

(Accepted 9 June 1998)

\section{Two memorable patients \\ What it's all about}

It is 3 am and rapid eye movement sleep is destroyed by the phone. Momentarily I am confused. The apology starts ... a young woman's voice. What time is it? Why me? In an Edinburgh hotel? Sense returns. Scotland was yesterday. I am at home. She is a senior house officer. I am Richard, on call consultant physician. Hello Rachel, no don't worry, I always sound like this.

Two (two?) patients need sectioning on the take ward. The clinical details are clear. Just remind me, Rachel, about the Mental Health Act. Thanks, right, section 5(2), right, 72 hours, right. Rachel, about those clinical details, just remind me again Rachel. Right, Rachel, about that act. Best to come in I think (best to come in and think, I think).

$330 \mathrm{am}$ : the take ward is on the boil. My house physician smiles, my senior house officer smiles, smiles and apologises; the nurses smile (I am sure that staff nurse is on days: she is, it's me who does days, she does both). Two security officers smile, "Come on son let's have you back in your room for the doc," they say, not unkindly. Back in the room he goes.
Rachel is, of course, right. Patients are seen, rights explained, psychiatrists consulted, and forms signed. Back to bed I go.

I drive home happily. This is my hospital. These are good doctors, these are good nurses and good security guards, working in a good NHS. At their best, as a team, at 330 in the morning. This is why I am doing medicine. This is what it's all about. I had forgotten some time ago and now it comes back. Oh and doctor, just before you go, why has it been so long since I last drove home with a smile on my face?

Richard Harrison, consultant physician, Stockton on Tees

We welcome articles up to 600 words on topics such as A memorable patient, A paper that changed my practice, My most unfortunate mistake, or any other piece conveying instruction, pathos, or humour. If possible the article should be supplied on a disk. Permission is needed from the patient or a relative if an identifiable patient is referred to. 